Review

\title{
Spinal Deformities and Advancement in Corrective Orthoses
}

\author{
Athar Ali ${ }^{1, *(\mathbb{D})}$, Vigilio Fontanari ${ }^{1}$, Marco Fontana ${ }^{1}\left(\mathbb{D}\right.$ and Werner Schmölz ${ }^{2}$ (I) \\ 1 Department of Industrial Engineering, University of Trento, 38122 Trento, Italy; \\ vigilio.fontanari@unitn.it (V.F.); marco.fontana-2@unitn.it (M.F.) \\ 2 Department of Trauma Surgery, Medizinische Universität Innsbruck, 6020 Innsbruck, Austria; \\ werner.schmoelz@i-med.ac.at \\ * Correspondence: athar.ali@unitn.it
}

\section{check for}

updates

Citation: Ali, A.; Fontanari, V.; Fontana, M.; Schmölz, W. Spinal Deformities and Advancement in Corrective Orthoses. Bioengineering 2021, 8, 2. https://dx.doi.org /10.3390/bioengineering8010002

Received: 19 November 2020 Accepted: 22 December 2020 Published: 25 December 2020

Publisher's Note: MDPI stays neutral with regard to jurisdictional claims in published maps and institutional affiliations.

Copyright: () 2020 by the authors. Licensee MDPI, Basel, Switzerland. This article is an open access article distributed under the terms and conditions of the Creative Commons Attribution (CC BY) license (https: / / creativecommons.org/ licenses/by/4.0/).

\begin{abstract}
Spinal deformity is an abnormality in the spinal curves and can seriously affect the activities of daily life. The conventional way to treat spinal deformities, such as scoliosis, kyphosis, and spondylolisthesis, is to use spinal orthoses (braces). Braces have been used for centuries to apply corrective forces to the spine to treat spinal deformities or to stabilize the spine during postoperative rehabilitation. Braces have not modernized with advancements in technology, and very few braces are equipped with smart sensory design and active actuation. There is a need to enable the orthotists, ergonomics practitioners, and developers to incorporate new technologies into the passive field of bracing. This article presents a review of the conventional passive braces and highlights the advancements in spinal orthoses in terms of improved sensory designs, active actuation mechanisms, and new construction methods (CAD/CAM, three-dimensional (3D) printing). This review includes 26 spinal orthoses, comprised of passive rigid/soft braces, active dynamics braces, and torso training devices for the rehabilitation of the spine.
\end{abstract}

Keywords: braces; scoliosis; corrective orthosis; wearable robotics; rehabilitation robotics

\section{Introduction}

Over 600,000 patients with spinal deformity are treated every year [1]. A spine deformity, such as kyphosis and idiopathic scoliosis, is an abnormality in the spine curvature. Diseases instigated by spinal stenosis, spondylolisthesis, and vertebral fractures, also result in spine deformity [2]. Spine deformity limits daily life activities and can damage the musculoskeletal, respiratory, and nervous systems [1]. The conventional treatment of spinal deformity is bracing, with the main objective to restrict the cobb angle progression and palliate the inevitability for surgery [3]. In the early 20th century, the use of braces was reduced due to surgical intervention, until the mid-20th century when complications started to emerge in spinal surgeries. This drew attention back to the conventional brace treatment [4].

Several literature studies [4-12] have been conducted to evaluate the effectiveness of corrective orthoses. These studies mainly considered the selection of the effective brace type and predictive factors (compliance, curve magnitude, growth stage, body mass index, and exercise potential) that contribute to promising outcomes.

This article presents a review of corrective orthoses to treat spinal deformities. It mainly focuses on developments in spinal orthosis technology, such as material, construction, rigidity, actuation, sensing, and characterization of different mechanical parameters. The devices developed for rehabilitation and training of the torso have also been reviewed in this study. The objective is to highlight advancements in brace technology and enable ergonomics practitioners, orthotists, and developers to design corrective orthosis for the treatment of injuries and deformities of the spine column. 


\section{Materials and Methods}

This systematic review on corrective orthosis was compiled using PRISMA guidelines. Records have been identified by searching through various research databases, such as PubMed, Medline, CINHAL, PEDro, EMBASE, Scopus, IEEE digital library, ASME digital library, and additional records through other sources. Initial searches showed 450 research references, which were further reduced to 360 by eliminating duplicate records. The remaining references were then screened by titles and abstracts to shortlist 125 references. References were excluded due to the reasons given in Figure 1. The remaining 90 references were considered eligible, and were then fully reviewed and included in the paper. Records that describe planning stages and have not yet taken physical form are not included in this review. This review includes references from journals, conferences, and commercially developed devices. There are a total of 26 devices mentioned in this study: 14 rigid and 5 soft braces, as well as seven other spinal rehabilitation and training devices.

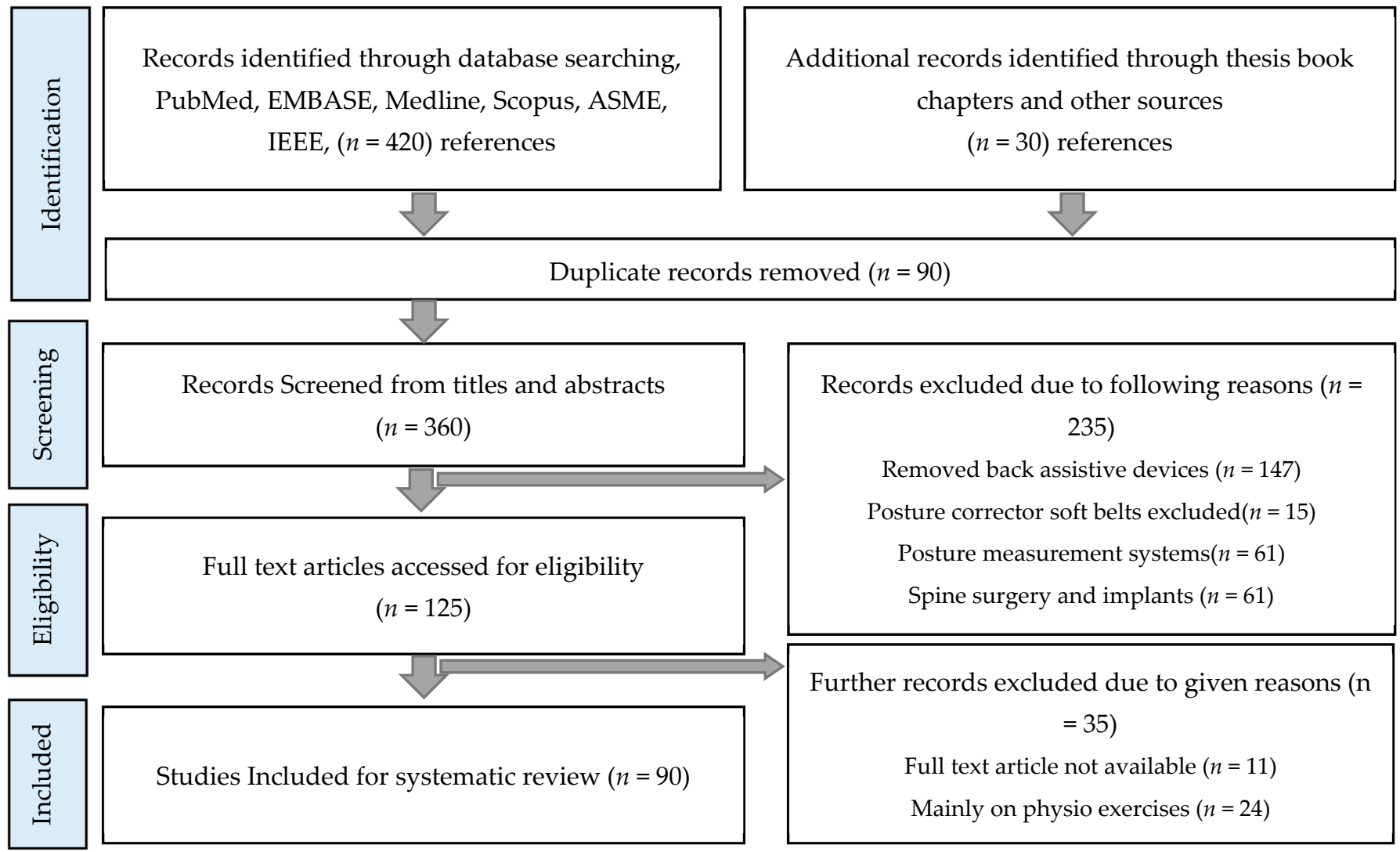

Figure 1. Systematic review article selection flowchart.

Several keywords and a combination of medical subject heading terms, such as braces, spinal orthosis, conservative treatment, scoliosis, spinal deformities, and rehabilitation robotics were used. Several data variables were considered while compiling this review, such as construction, structure, and correction principle.

\section{Corrective Orthoses (Braces)}

Braces have been used for centuries to treat spinal deformities like scoliosis, kyphosis, and lordosis. Many braces were developed in the mid-20th century and can be classified based on their construction, rigidity, symmetry, and openings (posterior/interior), as well as the principle of correction [13]. Some braces are constructed to apply de-rotation and tractive force to the spine [14] or pure spine bending [15], while others are custom-made to provide three-point pressure bending along with de-rotation on abnormal spine curves and apices $[16,17]$. 
The concept of bracing to treat scoliosis reattracted people's attention in the middle of the 20th century, due to an increase in complications in surgical treatment. Several rigid braces, such as Milwaukee [14,18-21], Boston [22-25], Lyon [26-28], and Chêneau braces [29-32], were developed for treating different scoliosis curves and have different correction principles.

To achieve better corrective results, hard braces need to be worn over $18 \mathrm{~h}$ a day, which seriously affects the activities of daily life. Therefore, nighttime braces were developed to reduce the wear time and enhance the compliance of the wearing braces. The Charleston brace [33] and the Providence brace [15] are two prominent nighttime braces. The Charleston brace is a part-time brace, effective for the patients with single thoracolumbar, single-bending scoliosis, and needs to be worn 8-10 h every night [6]. It has an aggressive over-correcting mechanism, and it keeps the patient's posture correct through lateral forces. Although rigid braces reduce the cobb angle significantly, a deep knowledge of curve pattern identification, basic biomechanics, and an understanding of functional diagnosis is needed for technicians to apply this brace.

Rigid braces are quite effective in the treatment of spinal curves. However, due to the static and rigid nature of the braces, they weaken the muscles around the spine and lead to other spine complexities. Although rigid braces are considered to be more effective in curve correction, considerable shortcomings are present in the current rigid braces: (i) braces limit motion, resulting in weakening of the muscles around the spine; (ii) they affect cardiopulmonary efficiency; (iii) they do not comprehend precise force control over a specific vertebra; (iv) braces are not modulated according to users' needs; (v) long construction time; (vi) braces causes skin breakdown and abnormal bone deformation.

Compared to rigid braces, soft braces are compliant in nature. They prevent curve progression and, in some cases correct it, depending upon the severity of the Cobb angle. They can also be used to stabilize the spine after spine fusion surgery. Soft braces maximize exercise potential and improve the comfort and quality of life. SpineCor [34], a soft brace, was developed to overcome the drawbacks of rigid braces-specifically, problems of breathability, bulkiness, and physical constraints. SpineCor uses five elastic bands wrapped around the torso, which are attached to the contoured body west and pelvic waist. These multiple elastic bands apply three-dimensional (3D) corrective forces as the individual moves and generate more muscular balance. SpineCor is a full-time brace, and its recovery time depends on the severity of the spinal curve and the effect of the treatment itself [34]. Unlike its rigid counterparts, which result in spinal stiffness and muscle atrophy, SpineCor retains the overall posture by increasing muscle activity by strengthening the muscle around the spine. Despite its advantages, SpineCor is considered to be less effective in terms of curve correction compared to rigid braces [35].

Weiss developed a soft brace known as the SpinealiteTM brace, which differs from SpineCor in several aspects [36,37]. The corrective band used in SpinealiteTM is considerably stiffer than the SpineCor brace. Therefore, tensions of the band will remain uniform over time and corrective forces will remain steady, conversely to SpineCor's unrestricted movements. A stiffer band makes SpinealiteTM comparatively less comfortable but brings more effective treatment results. This brace uses only one compression band to apply flexion corrective force on the sagittal plane and is suitable for treating lumbar lordosis.

A lateral force system TriaC brace was designed by Veldhuizen et al. [38]. It controls the rotation of the vertebral body by rotating the rear column to the concave side and the front column to the convex side. The effect of the correction in the frontal plane is similar to the rigid braces.

Several clinical results $[39,40]$ have been described to assess the effect of a soft brace compared to rigid braces, but there is not enough evidence to deduce explicit conclusions regarding the effectiveness of the interventions [36]. Some of these braces can be seen in Figure 2. Table 1 describes the corrective orthoses and summarizes their key aspects, such as the brace name, developer country, year of development, rigidity, construction method and material, symmetry, the principle of correction, and targeted scoliosis curves. The 
objective is to describe the existing technologies in order to develop corrective orthoses and their applicability.

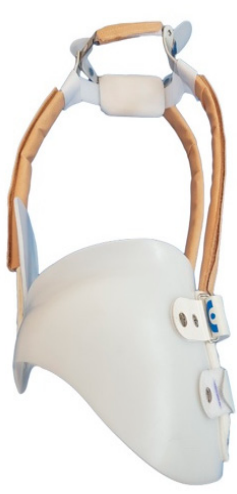

Milwaukee

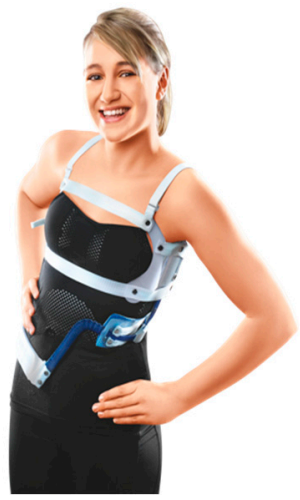

TriaC
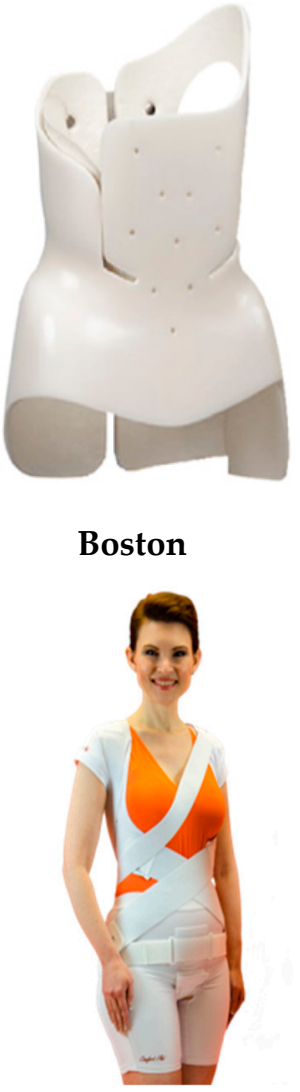

SpineCor

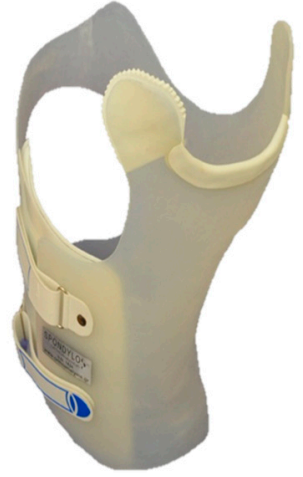

Chêneau

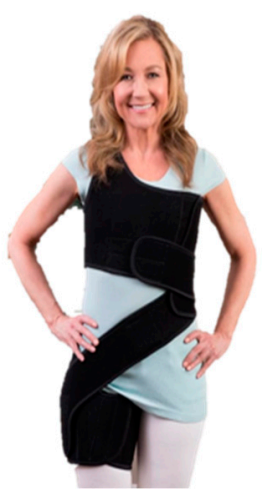

ScoliSMART

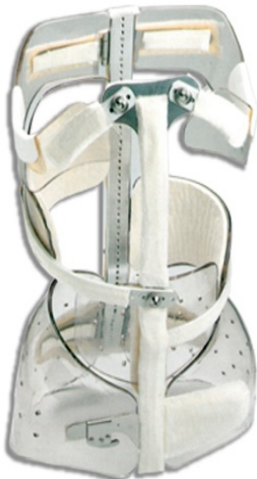

Lyon

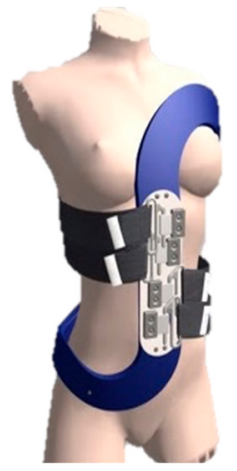

Flexpine

Figure 2. Rigid and soft corrective orthoses.

Table 1. Corrective orthoses (braces and suits).

\begin{tabular}{|c|c|c|c|}
\hline Device/Origin & Rigidity & Construction & Principle of Correction/Remarks \\
\hline $\begin{array}{l}\text { Milwaukee brace, } \\
\text { United States } 1945 \\
{[14,18]}\end{array}$ & Rigid & $\begin{array}{l}\text { Polyethylene, } \\
\text { aluminum, and steel }\end{array}$ & $\begin{array}{l}\text { Symmetrical design with a posterior opening. Previously used for } \\
\text { post-operative immobilization of neuromuscular scoliosis. Not used } \\
\text { anymore to treat scoliosis, but still used for Scheuermann's kyphosis } \\
\text { and high thoracic curves. }\end{array}$ \\
\hline $\begin{array}{l}\text { Wilmington brace, } \\
\text { United States } 1969 \\
\qquad[41]\end{array}$ & Rigid & $\begin{array}{l}\text { Polyethylene, } \\
\text { custom- } \\
\text { made/handmade }\end{array}$ & $\begin{array}{c}\text { Thoracic-lumbar-sacral orthosis (TLSO) with underarm symmetrical } \\
\text { design and anterior opening. Initially designed to treat curves } \\
\text { between } 25^{\circ} \text { and } 39^{\circ} \text { with apices at or inferior to T7. }\end{array}$ \\
\hline $\begin{array}{l}\text { Boston brace, } \\
\text { United States } 1972 \\
{[23,42]}\end{array}$ & Rigid & $\begin{array}{l}\text { Polyethylene, } \\
\text { prefabricated } \\
\text { envelope/models }\end{array}$ & $\begin{array}{l}\text { Symmetrical design with posterior opening. Developed for the } \\
\text { lumbar curve, extended to treat thoracolumbar and thoracic curves. } \\
\text { Reduced cost and fabrication time compared to Milwaukee. TLI } \\
\text { (thoracolumbar lordotic intervention) by Loon et al. [37] to ensure } \\
\text { forced lordosis at thoracolumbar spine. Applied when Cobb angle is } \\
\text { over } 25^{\circ}\end{array}$ \\
\hline $\begin{array}{c}\text { Chêneau and } \\
\text { derivatives, } \\
\text { France/Germany1960 } \\
{[31,43]}\end{array}$ & Rigid & $\begin{array}{l}\text { Polyethylene, } \\
\text { custom-made/CAD- } \\
\text { CAM, } \\
\text { handmade }\end{array}$ & $\begin{array}{l}\text { The principle of correction of Chêneau brace is a combination of } \\
\text { sagittal balance, regional de-rotation, physiological profile, and } \\
\text { three-point pressure bending system. A three-dimensional (3D) Rigo } \\
\text { System Chêneau brace (RSCB) and Chêneau light brace were } \\
\text { developed as an extension of the J Chêneau brace in } 1990 \text { and 2005, } \\
\text { respectively. }\end{array}$ \\
\hline
\end{tabular}


Table 1. Cont.

\begin{tabular}{ccc}
\hline Device/Origin & Rigidity & Construction \\
\hline & & \\
& & \\
Lyon brace, & & $\begin{array}{c}\text { Polymeta-crylate } \\
\text { France 1947 }\end{array}$ \\
{$[44,45]$} & Very rigid & $\begin{array}{c}\text { and radiolucent } \\
\text { duralumin }\end{array}$
\end{tabular}

Principle of Correction/Remarks

The correction principle is the three-point pressure system with rotation angular breathing (RAB). Three regional, two-dimensional (2D) individual moldings. A

3D asymmetrical rigid torsion brace (ART), which is a Lyon brace derivative. Correction principle is global detorsion. Moldings: 3D helicoidal correction with coupled movements. Material: $4 \mathrm{~m}$ polycarbonate, rigid. The sagittal plane is fixed in a physiological posture to improve a flat back if necessary. In the middle, under the breast, the clamping of the two hemi-shells realizes the "tube mayonnaise" effect with passive axial lengthening and geometric detorsion. The polycarbonate-skin interface is a soft contact type with a mechanical detorsion of a cylinder.

\begin{tabular}{ccc}
\hline $\begin{array}{c}\text { PASB, Italy 1976 } \\
\text { [46] }\end{array}$ & Rigid & $\begin{array}{c}\text { Polyethylene, } \\
\text { custom/handmade }\end{array}$ \\
$\begin{array}{c}\text { Charleston brace, } \\
\text { United States 1979 } \\
{[33,47]}\end{array}$ & Rigid & Polyethylene \\
\hline $\begin{array}{c}\text { Providence brace, } \\
\text { United States 1992 } \\
\text { [6] }\end{array}$ & Rigid & $\begin{array}{c}\text { Polyethylene, } \\
\text { custom-made/CAD- } \\
\text { CAM, } \\
\text { handmade }\end{array}$ \\
\hline
\end{tabular}

Progressive action short brace (PASB) is a TLSO for the correction of thoraco-lumbar, thoraco-lumbar-sacral, and idiopathic lumber curves.

Correction principle: Heuter-Volkmann principle TLSO, asymmetrical, anterior opening.Bending brace, side bending posture, single lumbar, thoracic, or thoracolumbar curves. Aggressive design for correction.

Surpasses the Charleston night brace due to less aggressive design. Asymmetric anterior opening. TLSO type, and curve correction by de-rotational and lateral forces as opposed to side bending posture, as seen in the Charleston brace. Very successful in treating flexible, single lumbar and thoracolumbar curves; however, it can be quite effective with thoracic and double curves.

\begin{tabular}{|c|c|c|c|}
\hline $\begin{array}{l}\text { Dynamic } \\
\text { Derotating Brace, } \\
\text { Greece } 1982[48]\end{array}$ & Rigid & $\begin{array}{l}\text { Polypropylene and } \\
\text { aluminum, custom } \\
\text { made/CAD-CAM, } \\
\text { handmade }\end{array}$ & $\begin{array}{l}\text { Developed as a modification of the Boston brace in } 1982 \text {, in Greece. It } \\
\text { opens posteriorly, with a TLSO-type underarm brace with aluminum } \\
\text { blades set to produce anti-rotating and de-rotating effects on the } \\
\text { trunk and thorax of scoliosis patients.It is recommended for } \\
\text { extremely high thoracic curves when the apex vertebra is T5 or above. }\end{array}$ \\
\hline $\begin{array}{l}\text { Rosenberger } \\
\text { brace, United } \\
\text { States } 1983[49]\end{array}$ & Rigid & Polyethylene & $\begin{array}{l}\text { Correction principle: three-point pressure system.Asymmetrical, } \\
\text { anterior opening, TLSO, reduces the curves with a translator and } \\
\text { de-rotational loads. The limitation is its retrospective design. }\end{array}$ \\
\hline $\begin{array}{c}\text { 3D Sibilla brace } \\
\text { [50] }\end{array}$ & $\begin{array}{l}\text { Low } \\
\text { rigidity }\end{array}$ & - & $\begin{array}{l}\text { Proposed for mild curve progression for a Cobb angle }<30^{\circ} \text { that } \\
\text { cannot be treated by SEAS * exercises. The brace is recommended to } \\
\text { wear for } 18 \text { to } 20 \mathrm{~h} \text { daily, up to Risser stage } 3 \text {. }\end{array}$ \\
\hline $\begin{array}{c}\text { Sforzesco brace, } \\
\text { Italy [50] }\end{array}$ & Very rigid & $\begin{array}{c}\text { Copolyester } \\
\text { radiolucent } \\
\text { duralumin, } \\
\text { custom-made/CAD- } \\
\text { CAM, } \\
\text { handmade }\end{array}$ & $\begin{array}{l}\text { 3D active, symmetrical, incorporating the features of Milwaukee, } \\
\text { Lyon, Sibilla, Risser cast, and Chêneau braces. Used for severe } \\
\left.\text { adolescent scoliosis (Cobb } 45^{\circ}-50^{\circ}\right) \text { when surgery is not a possible } \\
\text { option or patients do not want it to be operated on. It is also a } \\
\text { full-time brace and is recommended to be worn over } 18 \mathrm{~h} \text { a day. }\end{array}$ \\
\hline $\begin{array}{c}\text { SpoRT Brace } \\
{[26,50]}\end{array}$ & Rigid & $\begin{array}{l}\text { Polycarbonate, } \\
\text { aluminum }\end{array}$ & $\begin{array}{l}\text { The SPoRT bracing (three-dimensional elongation pushing in a } \\
\text { down-up direction) is different from the other corrective systems: } \\
\text { symmetric design, three-point, traction, and postural and } \\
\text { movement-based. }\end{array}$ \\
\hline $\begin{array}{l}\text { Jewett hyperexten- } \\
\text { sionbrace, } \\
{[51]}\end{array}$ & Rigid & $\begin{array}{c}\text { Metallic, } \\
\text { prefabricated }\end{array}$ & $\begin{array}{c}\text { Used to treat hyperkyphosis. It cannot handle rotational deformities } \\
\text { of scoliosis. Stable framework construction restricts lateral flexion } \\
\text { and hyperextension of the vertebral column, and provides } \\
\text { stabilization in the sagittal plane. }\end{array}$ \\
\hline $\begin{array}{l}\text { Flexpine brace, } \\
\text { South Korea [52] }\end{array}$ & Semi-rigid & $\begin{array}{l}\text { 3D-printed, elastic } \\
\text { tissue, foldable } \\
\text { plastic body }\end{array}$ & $\begin{array}{l}\text { Lightweight, } 4 \mathrm{~mm} \text {-thick brace. } \\
\text { 3D-printed brace made from foldable plastic. } \\
\text { Allows mobility and enhances exercise's potential to treat scoliosis. }\end{array}$ \\
\hline
\end{tabular}


Table 1. Cont.

\begin{tabular}{|c|c|c|c|}
\hline Device/Origin & Rigidity & Construction & Principle of Correction/Remarks \\
\hline $\begin{array}{l}\text { Flexpine brace, } \\
\text { South Korea [52] }\end{array}$ & Semi-rigid & $\begin{array}{l}\text { 3D-printed, elastic } \\
\text { tissue, foldable } \\
\text { plastic body }\end{array}$ & $\begin{array}{l}\text { Lightweight, } 4 \mathrm{~mm} \text {-thick brace. } \\
\text { 3D-printed brace made from foldable plastic. } \\
\text { Allows mobility and enhances exercise's potential to treat scoliosis. }\end{array}$ \\
\hline $\begin{array}{c}\text { SpineCor } \\
\text { dynamic brace, } \\
\text { Canada } 1993 \\
{[34,53]}\end{array}$ & Elastic & $\begin{array}{c}\text { Elastic tissue, } \\
\text { Prefabricated } \\
\text { envelope/models }\end{array}$ & $\begin{array}{l}\text { Dynamic bracing solution for idiopathic scoliosis and round back } \\
\text { (hyperkyphosis) deformity. SpineCor treatment is suitable for } \\
\text { children from the age of five with idiopathic scoliosis and certain } \\
\text { syndrome-related scoliosis curves from } 20^{\circ}-50^{\circ} \text {. (Treatment is } \\
\text { recommended for as low as } 15^{\circ} \text { for children with a higher risk of } \\
\text { progression.) }\end{array}$ \\
\hline $\begin{array}{c}\text { SpinealiteTM } \\
\text { brace }[36,37]\end{array}$ & Elastic & $\begin{array}{c}\text { Elastic tissue, } \\
\text { prefabricated } \\
\text { envelope/models }\end{array}$ & $\begin{array}{l}\text { SpinealiteTM is used to treat lumbar lordosis. It uses a single band } \\
\text { for the back compression force, which is quite helpful for the } \\
\text { correction of flexion in the sagittal plane. }\end{array}$ \\
\hline $\begin{array}{c}\text { Triac brace, } \\
\text { Netherlands } \\
\quad[38,39]\end{array}$ & $\begin{array}{l}\text { Low } \\
\text { rigidity }\end{array}$ & $\begin{array}{l}\text { Soft plastic and } \\
\text { metallic connections, } \\
\text { prefabricated } \\
\text { envelope/models }\end{array}$ & $\begin{array}{c}\text { The flexible Triac brace was designed to improve cosmetic } \\
\text { appearance and comfort. It was developed for primary curve } \\
\text { correction in idiopathic scoliosis (IS). Planes of action are frontal and } \\
\text { sagittal. Not recommended for the treatment of thoracic or double } \\
\text { curves. }\end{array}$ \\
\hline $\begin{array}{c}\text { ScoliSmart, USA } \\
{[54]}\end{array}$ & Soft suit & $\begin{array}{c}\text { Prefabricated/fabric, } \\
\text { elastic }\end{array}$ & $\begin{array}{l}\text { ScoliSmart utilizes the energy of a human's natural movement to } \\
\text { generate new muscle memory. This new muscle memory decreases } \\
\text { and stabilizes asymmetrical muscle firing, thus reducing the risk of } \\
\text { curve progression and helping the spine unravel naturally, so it is } \\
\text { never forced. }\end{array}$ \\
\hline
\end{tabular}

* SEAS: scientific exercises approach to scoliosis.

The current statistical studies $[5,9,10]$ have determined that there is no adequate evidence to reach one concurrent decision about what type of brace is the best among all other types. The adequacy of the scoliosis treatment using braces remains controversial, due to inadequacy in the selection criteria of patients and the definition of brace efficacy. In order to compare the studies and validation of their reliability, the Scoliosis Research Society (SRS) has standardized criteria for the clinical trials of scoliosis patients with brace treatment. The SRS criteria include initial curve angles of $25-40^{\circ}$, age of 10 years or older at the time of brace prescription, no prior treatment, and being at Risser stages 0-2 [55]. The International Scientific Society on Scoliosis Orthopedic and Rehabilitation Treatment (SOSORT) produced its first guidelines in 2005, and renewed them in 2011 and 2016 to standardize them and align the use of braces and exercises into clinical practice of conservative treatment for idiopathic scoliosis (CTIS) [56].

\section{Advancement in Spinal Rehabilitation Orthoses}

A few researchers have tried to incorporate the technologies of the assistive orthoses into the corrective orthoses, to resolve several challenges faced by corrective orthoses, such as rigidity, lack of adjustability, higher construction time, sensorless design, and lack of force control over the specific vertebra.

\subsection{Mobility and Actuation Technology}

Mobility is key when it comes to treatment with braces. Conventional braces are rigid, passive, and do not allow mobility to the spine, which results in spine stiffness. Mobility can be achieved by either passive or active actuation. Actuation technologies in the area of assistive orthoses are quite matured with regard to achieving the goal of assisting the spine. Some of these actuation technologies have been introduced in corrective orthoses as well, such as the development of Spinecor and ScoliSMART, which are passive soft orthoses and use elastic material to apply corrective forces with the dynamic movement 
of the human body. Unfortunately, these passive braces do not provide force control over specific vertebra to apply the corrective forces.

To address the issues of mobility and apply controlled corrective forces over specific vertebra, the University of Colombia developed the RoSE dynamic brace. It uses two parallel Stewart platforms to apply forces in all directions, as shown in Figure 3. Forces and displacements applied by the RoSE can be measured by built-in pressure sensors and position sensors inside the actuator [17]. The RoSE exoskeleton is a big advancement in the area of active corrective orthoses, but has certain limitations. It uses eight series actuators that require a significant amount of power and also increase the device weight. This could be a limit in the use of RoSE, since these braces are supposed to be worn $18 \mathrm{~h}$ a day.

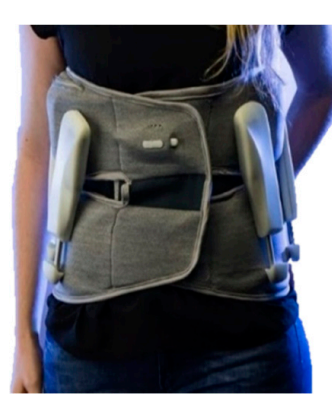

Japet(ATLAS)

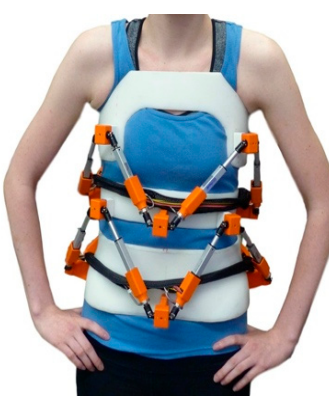

RoSE Dynamic Brace

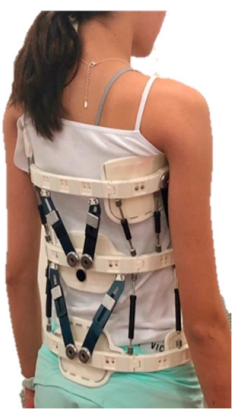

Green Sun Medical

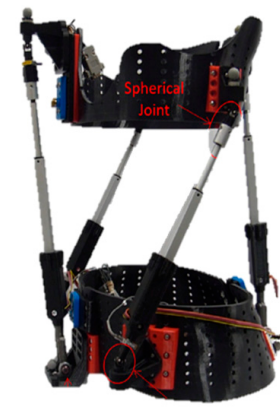

WRAPS

Figure 3. Smart rehabilitation orthoses for the spinal column.

Spondylolisthesis is another type of spinal deformity, in which one of the vertebrae in the spine slips out of the proper position onto the vertebra below it, putting pressure on the nerve and a disc. Atlas Japet [13] developed an active disk decompression device that particularly helps to relieve people suffering from back pain caused by a herniated disk. Excessive vertebral compression of the intervertebral disks results in back pain. Atlas Japet alleviates the pain by applying distraction force on the vertebral column to increase the inter-joint space between vertebras. Exo-dynamics developed an active spinal brace called ExMS-1 [57], which offers automatic, customizable back support without restricting mobility. The goal of ExMS-1 is to prevent back pain from becoming serious spinal injury.

Both Atlas Japet and ExMS-1 use series actuators that consume a lot of power. It is important to explore other actuation technologies that consume less power to reduce metabolic cost, as braces need to be worn for longer durations. One such mechanism is a twisted string actuation (TSA) [58]. TSA is translational transmission systems based on twisted strings coupled with electric motors, and results in lightweight, compact, and mechanically simple actuators [59]. TSAs are being used in a variety of wearable applications and have been used recently in spinal assistive devices [60]. Therefore, they have great potential to be used in the development of active dynamic braces.

\subsection{Sensory Designs and Parameter Characterization}

To treat a spinal deformity effectively, it is important to measure the physiological and mechanical parameters of the torso. Measuring the progression of the spine and adjusting the brace accordingly will expedite the process of recovery. Green Sun Medical developed a brace that provides physicians and patients with real-time performance metrics, utilizing a cloud-based health platform [61]. Measuring muscle activities would give feedback on muscle activation during the bracing time. This information is crucial from a physiotherapy point of view, in order to monitor the strengthening of the muscles. Myontec developed intelligent clothing technology to monitor the muscles' activities, integrated with movement sensors for sports and rehabilitation purposes [62].

Outcomes of the brace treatment are associated with how effectively a brace is being worn. Force sensors and compliance monitors have been developed to monitor the quality of the brace usage. Thermobrace is a temperature sensor that is applied to the brace to monitor 
its actual wearing. It helps to optimize the therapies and helps doctors to understand the real effectiveness of the braces $[11,63,64]$. One of the key concerns in brace treatment is the lack of information on the forces that are being applied by the brace on the torso. Lou et al. [65] designed a wireless sensor network system to determine the biomechanics of spinal braces and continuously monitor the forces exerted by the brace on the spine. This system helps to examine the force distribution inside the brace during daily activities.

The effectiveness of the brace treatment depends on how the brace has been worn. It is important to wear the brace with the prescribed tightness to achieve a better outcome from the treatment. Lou et.al [66] developed an active intelligent brace system, which maintains the interface pressure in a prescribed range between the body and the brace. The brace uses an air bladder, which inflates to control the pressure between brace and body. An active intelligent brace increases the effective time of wearing the brace in prescribed tightness from $28 \%$ to $47 \%$ [66-68].

Braces correct the abnormal posture of the spine by applying several displacements at different levels of the torso. This is usually attained by adding soft pads or by adjusting the geometry of the brace design. These displacements result in corrective forces that are transmitted to the spine through soft tissues and the rib cage within the torso. Therefore, the amount of the curve correction depends on the stiffness of the torso, i.e., the stiffness of the soft tissues and stiffness of the spine. The stiffness characteristics of the torso may vary over time and during the course of the treatment, due to variation in the torso geometry, bone maturity spine curve, and fat distribution. Therefore, it is important to consider the torso stiffness characteristics along with the spine geometry to effectively design a brace. Park et al. [17] and Murray et al. [69] characterized torso stiffness in male and female patients using the RoSE dynamic brace.

Several other smart and active devices have been developed to characterize different physical parameters of the spine. These devices either help improve the scoliosis treatment or enhance the physiotherapy/training potential of the patients. Khan et al. [70,71] have developed the cable-driven trunk support trainer (TruST), which is helpful for the training of the seated posture for patients suffering from musculoskeletal and neurological disorders, where they have compromised postural stability. Based on a patient's maximum trunk excursion, TruST control algorithms create a circular planar force tunnel around the trunk and provides as-needed assistance forces to the torso while performing the intended movements [72].

People with trunk impairment do not have enough strength in their trunk muscles to keep an upright posture or control the weight shifts to perform certain movements. Several passive orthoses are available to support the trunk by passively placing the torso and not allowing any degree of freedom to the trunk. Ophaswongse et al. [73] developed the wheelchair robot for active postural support (WRAPS). WRAPS supports the torso's weight and is capable of replicating the patient's trunk range of motion (tROM) without full activation of the trunk muscles. This is crucial for the people who do not have trunk control in antigravity postures, such as standing and sitting, when a reaching task is executed [74].

Table 2 describes the devices that are being used either to treat scoliosis effectively or for the training of the torso to enhance exercise potential. Several parameters, such as device name, actuation type, structure, application, and others, have been considered in the table. 
Table 2. Smart rehabilitation orthoses for the spinal column.

\begin{tabular}{|c|c|c|c|c|}
\hline Device & Actuation & Structure & Application & Remarks \\
\hline $\begin{array}{l}\text { Greensun } \\
\text { medical brace, } \\
\text { United States } \\
{[61]}\end{array}$ & $\begin{array}{c}\text { Passive } \\
\text { (elastic and metallic } \\
\text { connections, } \\
\text { prefabricated and } \\
\text { adjusted for each } \\
\text { patient) }\end{array}$ & Semi-rigid & $\begin{array}{l}\text { Treat idiopathic } \\
\text { scoliosis }\end{array}$ & $\begin{array}{l}\text { It is a low-rigidity brace, consisting of semi-rigid } \\
\text { segments encircling the torso, which are joined by } \\
\text { the elastic elements. These elastic elements give } \\
\text { required immobilization by engendering } \\
\text { stabilizing forces while allowing the relative } \\
\text { motion of semi-rigid segments. Real-time } \\
\text { monitoring of the correction progress to adjust } \\
\text { the brace. }\end{array}$ \\
\hline $\begin{array}{c}\text { Inflatable } \\
\text { intelligent } \\
\text { active brace } \\
{[66]}\end{array}$ & $\begin{array}{l}\text { Active (pneumatic } \\
\text { bladder) }\end{array}$ & Rigid & $\begin{array}{c}\text { Treat idiopathic } \\
\text { Scoliosis }\end{array}$ & $\begin{array}{l}\text { Use the air bladder to control interface pressure } \\
\text { by inflating the bladder. The control system is } \\
\text { comprised of a microcontroller, a force feedback } \\
\text { component, and a force transducer. }\end{array}$ \\
\hline $\begin{array}{c}\text { Japet } \\
\text { (Atlas) [75] }\end{array}$ & $\begin{array}{l}\text { Active } \\
\text { (four electric } \\
\text { actuators) }\end{array}$ & Rigid & $\begin{array}{l}\text { Pain relief, } \\
\text { recover mobility }\end{array}$ & $\begin{array}{l}\text { Extends the spine to release the pain. The } \\
\text { adaptable system maintains complete freedom of } \\
\text { movement without restricting muscular activity. }\end{array}$ \\
\hline $\begin{array}{c}\text { ExMs-1 by } \\
\text { Exo-dynamics } \\
{[57]}\end{array}$ & $\begin{array}{l}\text { Active (four electric } \\
\text { actuators) }\end{array}$ & Rigid & $\begin{array}{l}\text { Pain relief, } \\
\text { assistance while } \\
\text { bending }\end{array}$ & $\begin{array}{l}\text { Extends the spine and offers automatic, } \\
\text { customizable back support without sacrificing } \\
\text { mobility. This device is not intended to diagnose, } \\
\text { treat, cure, or prevent any disease. }\end{array}$ \\
\hline $\begin{array}{c}\text { RoSE dynamic } \\
\text { brace }[17,69]\end{array}$ & $\begin{array}{l}\text { Active } \\
\text { (electric, series } \\
\text { elastic actuators) }\end{array}$ & $\begin{array}{l}\text { Rigid (parallel } \\
\text { Stewart } \\
\text { platforms) }\end{array}$ & $\begin{array}{l}\text { Treat idiopathic } \\
\text { scoliosis, torso } \\
\text { stiffness } \\
\text { characterization }\end{array}$ & $\begin{array}{l}\text { Three-point bending (push, movement, and } \\
\text { elongation are other actuation mechanisms) and } \\
\text { plane of action (3D, frontal, frontal horizontal, } \\
\text { sagittal, and brace map classification). }\end{array}$ \\
\hline $\begin{array}{c}\text { TruST } \\
{[70-72]}\end{array}$ & $\begin{array}{l}\text { Active } \\
\text { (electric, servo } \\
\text { motors) }\end{array}$ & $\begin{array}{c}\text { Rigid } \\
\text { (pulley cable } \\
\text { system) }\end{array}$ & $\begin{array}{l}\text { Trunk support } \\
\text { trainer }\end{array}$ & $\begin{array}{l}\text { TruST is a cable pulley system; it uses four } \\
\text { motors mounted on a stationary platform to } \\
\text { apply forces through an adjustable but rigid belt } \\
\text { on the trunk. TruST assists patients who have lost } \\
\text { postural stability of the torso. }\end{array}$ \\
\hline WRAPS $[73,74]$ & $\begin{array}{c}\text { Active } \\
\text { series electric } \\
\text { actuators }\end{array}$ & Rigid & $\begin{array}{l}\text { Torso postural } \\
\text { Support }\end{array}$ & $\begin{array}{l}\text { WRAPS is a parallel robotic device consisting of } \\
\text { two rings over the chest and hips connected by } \\
\text { 2RPS-2UPS architecture. WRAPS can modulate } \\
\text { forces/displacements applied to the torso in four } \\
\text { degrees of freedom. }\end{array}$ \\
\hline
\end{tabular}

\section{3. $C A D / C A M$ and Smart Materials}

Three-dimensional printing revolutionized the conventional way of constructing braces. For decades, the conventional way to fabricate braces was by plaster cast, which involved manual measurements of the patient's torso and designing a handmade brace. Technological revolution has enabled technicians to take body measurements using a photogrammetric scanning system, which is even faster than laser scanners [76]. Photogrammetric scanning systems have been proven to be effective for the fabrication of custom-made spinal orthoses, especially for patients with mobility impairments, as it allows them to capture instantaneously the torso shape with high accuracy $(<1 \mathrm{~mm})$ [77]. This allowed the fabrication of the CAD/CAM braces using 3D printing. These 3D-printed braces solve the socio-economic barrier of typical braces, and seem more appealing to the patients. Hence, the braces maximize patients' willingness to wear a brace on a daily basis. It provides unparalleled personalization, incredible breathability, and reduces fabrication time. The Flexpine brace [52] is a semi-rigid brace used for conventionally treating scoliosis. It is 3D-printed brace, which uses $4 \mathrm{~mm}$-thickn foldable plastic as its frame and elastic bands to apply corrective forces. It offers great mobility to the spine and overcomes the limitations of typical rigid braces. Various other braces, such as Boston, Chêneau, and Lyon, are also being $3 \mathrm{D}$ printed to enhance the breathability and reduce the fabrication time. 
Several studies have demonstrated significant improvement in the results using $\mathrm{CAD} / \mathrm{CAM}$ braces compared to the traditional approach, adding concrete scientific evidence (level of evidence II) [78-80]. However, these studies cannot offer a prior guarantee for better treatment results, as several other factors play a crucial role in brace treatment. Cobetto et al. [81,82], in two randomized controlled trials (RCTs), concluded that the combination of finite element modelling (FEM) and a CAD/CAM approach can further improve in-brace correction (IBC). The FEM braces exhibited $48 \%$ and $47 \%$ IBC for lumbar and thoracic curves, respectively, compared to $26 \%$ and $25 \%$ of CAD/CAM braces. Axial rotation correction of $46 \%$ compared to $30 \%$ by CAD/CAM braces. Moreover, the FEM braces were $50 \%$ thinner and had $20 \%$ less covering surface, making them more breathable for the wearer [81,82].

Various 3D printing techniques have been adapted in medical applications, such as stereolithography (SLA), Polyjet modeling (PJM), selective laser sintering (SLS), and fused deposition modeling (FDM). High equipment costs (especially for SLS and PJM) and processing times are the major limiting factors in the production of large orthotic devices using 3D printing. FDM is the most suitable and least expensive method to produce scoliosis braces among these 3D printing techniques, despite having a bit less dimensional accuracy. A few studies have recommended the use of 3D printing to construct orthotic devices [83-85]. The majority of the researchers have fixated on the feasibility of developing devices with accurate geometrical dimensions and desired shapes, but quite a few studies have reported the cost and mechanical performances of these devices. Furthermore, filament datasheets often refer to the mechanical properties of the bulk material before 3D printing, while the mechanical properties of the printed parts is inadequate and primarily focused on tensile properties [86]. Moreover, it is crucial to evaluate the toughness of the material through impact tests by measuring the energy absorbed for the duration of high strain rate conditions before failure. This behavior definitely varies with different production technologies, and the materials currently used for 3D printed orthotic devices do not provide the rigidity needed to correct the spine posture [85]. For these reasons, it is not yet possible to predict how the combination of virtual modeling and additive manufacturing processes affects the mechanical properties of a 3D-printed brace.

Since one of the major drawbacks of corrective orthoses is the uncomfortable rigidity that does not allow the necessary range of motion, the introduction of the principle of variable stiffness in design seems to be quite promising. This can be obtained either using new smart materials or developing specific design solutions. Smart materials have gained substantial consideration in medical applications. In particular, shape memory alloys (SMAs) are most generally employed for their super elasticity (SE) in orthopedic treatment. Chan et al. [87] developed a flexible scoliotic brace using SMAs. Among the suitable systems for variable stiffness, the jamming-based systems are emerging with a new set of possibilities [88,89]. Layer-jamming mechanisms have certain advantages, such as compactness, being lightweight, high resistance force, and fast reaction time. Jamming structures also possess the shape-locking capability, which can help to reduce the metabolic cost. They can be fabricated entirely using a 3D printing technique. Choi et al. [90] proposed that these structures can be used to develop the spinal assistance robot and in various other wearable applications.

\section{Conclusions}

The technologies presented in this article are a chunk of the bigger picture of improved spinal deformity treatment. Spinal deformity treatment remains an extremely qualitative process and relies heavily on the experience of the orthotist, physicians, physiotherapists, and patient compliance. The recommended developments will push spinal deformity treatment into more evidence-based practice. These technologies can be used to determine when bracing is most effective and how to improve the quality of life, as well as patient outcomes. This review article has focused on the following major areas: 
1. Existing conventional braces and their key aspects, such as construction, materials, rigidity, and correction principle;

2. Advancement in brace spinal orthoses technologies in terms of mobility and actuation;

3. Use of sensors to track the brace compliance, interface pressure, force distribution, and torso parameter characterization;

4. Developments in brace construction technologies, such as CAD/CAM, 3D printing and smart materials.

Taking into consideration that these areas of research need to be streamlined and integrated, the direction of spinal deformity treatment needs to be not only the development of new kinds of braces and greater randomized control trials, but also the designing the technologies to supplement these braces. While technology in force and temperature sensors, as well as imaging and manufacturing methods, has progressed immensely, bracing has not taken advantage of this innovation. Prevalent implementation of these technologies will go a long way to successful patient outcomes from bracing for spinal deformities.

Author Contributions: Conceptualization, methodology, investigation, resources, data curation, and writing—original draft preparation, A.A.; writing—review and editing, V.F. and W.S.; visualization and supervision V.F. and M.F.; project administration and funding acquisition, V.F. and M.F. All authors have read and agreed to the published version of the manuscript.

Funding: This project has received funding from the Italian Ministry for Education, University, and Research (MIUR) through the "Departments of Excellence" program.

Institutional Review Board Statement: Not applicable.

Informed Consent Statement: Not applicable.

Data Availability Statement: Data available in a publicly accessible repository.

Acknowledgments: Not applicable.

Conflicts of Interest: The authors declare no conflict of interest.

\section{References}

1. Ogilvie, J. Adolescent idiopathic scoliosis and genetic testing. Curr. Opin. Pediatr. 2010, 22, 67-70. [CrossRef]

2. Soultanis, K.C.; Payatakes, A.H.; Chouliaras, V.T.; Mandellos, G.C.; Pyrovolou, N.E.; Pliarchopoulou, F.M.; Soucacos, P.N. Rare causes of scoliosis and spine deformity: Experience and particular features. Scoliosis 2007. [CrossRef]

3. Weinstein, S.L.; Dolan, L.A.; Wright, J.G.; Dobbs, M.B. Effects of bracing in adolescents with idiopathic scoliosis. N. Engl. J. Med. 2013. [CrossRef] [PubMed]

4. Niu, X.; Yang, C.; Tian, B.; Li, X.; Zheng, S.; Cong, D.; Han, J.; Agrawal, S.K. Investigation of robotic braces of patients with idiopathic scoliosis (IS)—Review of the literature and description of a novel brace. J. Mech. Med. Biol. 2018. [CrossRef]

5. McAviney, J.; Mee, J.; Fazalbhoy, A.; Du Plessis, J.; Brown, B.T. A systematic literature review of spinal brace/orthosis treatment for adults with scoliosis between 1967 and 2018: Clinical outcomes and harms data. BMC Musculoskelet. Disord. 2020, $21,87$. [CrossRef]

6. Zaina, F.; De Mauroy, J.C.; Grivas, T.; Hresko, M.T.; Kotwizki, T.; Maruyama, T.; Price, N.; Rigo, M.; Stikeleather, L.; Wynne, J.; et al. Bracing for scoliosis in 2014: State of the art. Eur. J. Phys. Rehabil. Med. 2014, 51, 93-110.

7. Karavidas, N. Bracing In The Treatment Of Adolescent Idiopathic Scoliosis: Evidence To Date. Adolesc. Health. Med. Ther. 2019. [CrossRef]

8. Zhang, Y.; Li, X. Treatment of bracing for adolescent idiopathic scoliosis patients: A meta-analysis. Eur. Spine J. 2019, 28 , 2012-2019. [CrossRef] [PubMed]

9. Kaelin, A.J. Adolescent idiopathic scoliosis: Indications for bracing and conservative treatments. Ann. Transl. Med. 2020. [CrossRef]

10. Kuroki, H. Brace treatment for adolescent idiopathic scoliosis. J. Clin. Med. 2018, 7, 136. [CrossRef]

11. Donzelli, S.; Zaina, F.; Martinez, G.; Di Felice, F.; Negrini, A.; Negrini, S. Adolescents with idiopathic scoliosis and their parents have a positive attitude towards the Thermobrace monitor: Results from a survey. Scoliosis Spinal Disord. 2017. [CrossRef] [PubMed]

12. Chan, A.; Lou, E.; Hill, D. Review of current technologies and methods supplementing brace treatment in adolescent idiopathic scoliosis. J. Child. Orthop. 2013. [CrossRef] [PubMed]

13. Grivas, T.B.; de Mauroy, J.C.; Wood, G.; Rigo, M.; Hresko, M.T.; Kotwicki, T.; Negrini, S. Brace classification study group (BCSG): Part one-definitions and atlas (Retraction of Vol 11, art no 43, 2016). Scoliosis Spinal Disord. 2016. [CrossRef] [PubMed] 
14. Lonstein, J.E.; Winter, R.B. The Milwaukee brace for the treatment of adolescent idiopathic scoliosis. A review of one thousand and twenty patients. J. Bone Joint Surg. Am. 1994. [CrossRef] [PubMed]

15. Wiemann, J.M.; Shah, S.A.; Price, C.T. Nighttime bracing versus observation for early adolescent idiopathic scoliosis. J. Pediatr. Orthop. 2014. [CrossRef] [PubMed]

16. Rigo, M.; Weiss, H.R. The Chêneau concept of bracing-biomechanical aspects. Stud. Health Technol. Inform. 2008, 135, 303-319.

17. Park, J.H.; Stegall, P.R.; Roye, D.P.; Agrawal, S.K. Robotic Spine Exoskeleton (RoSE): Characterizing the 3-d stiffness of the human torso in the treatment of spine deformity. IEEE Trans. Neural Syst. Rehabil. Eng. 2018. [CrossRef]

18. Maruyama, T.; Takesita, K.; Kitagawa, T.; Nakao, Y. Milwaukee brace. Physiother. Theory Pract. 2011. [CrossRef]

19. Noonan, K.J.; Weinstein, S.L.; Jacobson, W.C.; Dolan, L.A. Use of the Milwaukee brace for progressive idiopathic scoliosis. J. Bone Joint Surg. Am. 1996. [CrossRef]

20. Blount, W.P.; Schmidt, A.C.; Keever, E.D.; Leonard, E.T. The Milwaukee brace in the operative treatment of scoliosis. JBJS 1958, 40, 511-525. [CrossRef]

21. ORTHOGEA SRL Milwaukee Brace. Available online: https://www.orthogea.com/product-detail/corsetto-milwaukee/ (accessed on 19 November 2020).

22. Danielsson, A.J.; Hasserius, R.; Ohlin, A.; Nachemson, A.L. A prospective study of brace treatment versus observation alone in adolescent idiopathic scoliosis: A follow-up mean of 16 years after maturity. Spine (Phila. Pa. 1976). 2007. [CrossRef] [PubMed]

23. Emans, J.B.; Kaelin, A.; Bancel, P.; Hall, J.E.; Miller, M.E. The boston bracing system for idiopathic scoliosis: Follow-up results in 295 patients. Spine (Phila. Pa. 1976). 1986. [CrossRef] [PubMed]

24. Heary, R.F.; Kumar, S.; Bono, C.M. Bracing for scoliosis. Neurosurgery 2008. [CrossRef] [PubMed]

25. Corrective orthosis boston brace. Available online: https://commons.wikimedia.org/wiki/File:Bostonbrace.jpg (accessed on 10 July 2020).

26. Negrini, S.; Marchini, G. Efficacy of the symmetric, patient-oriented, rigid, three-dimensional, active (SPoRT) concept of bracing for scoliosis: A prospective study of the Sforzesco versus Lyon brace. Eura. Medicophys. 2007, 43, 171-181. [PubMed]

27. Zaina, F.; Negrini, S.; Fusco, C.; Atanasio, S. How to improve aesthetics in patients with Adolescent Idiopathic Scoliosis (AIS): A SPoRT brace treatment according to SOSORT management criteria. Scoliosis 2009, 4, 18. [CrossRef]

28. ORTHOGEA SRL Lyon Brace. Available online: https://www.orthogea.com/product-detail/corsetto-lionese/ (accessed on 18 November 2020).

29. Hopf, C.; Heine, J. Long-term results of the conservative treatment of scoliosis using the Cheneau brace. Z. Orthop. Ihre Grenzgeb. 1985, 123, 312-322. [CrossRef]

30. Zaborowska-Sapeta, K.; Kowalski, I.M.; Kotwicki, T.; Protasiewicz-Fałdowska, H.; Kiebzak, W. Effectiveness of Chêneau brace treatment for idiopathic scoliosis: Prospective study in 79 patients followed to skeletal maturity. Scoliosis 2011. [CrossRef]

31. De Giorgi, S.; Piazzolla, A.; Tafuri, S.; Borracci, C.; Martucci, A.; De Giorgi, G. Chêneau brace for adolescent idiopathic scoliosis: Long-term results. Can it prevent surgery? Eur. Spine J. 2013. [CrossRef]

32. Wikimedia Commons Cheneau Brace Image. Available online: https://commons.wikimedia.org/wiki/File:Crass_Cheneau_ brace.jpg (accessed on 10 July 2020).

33. Lee, C.S.; Hwang, C.J.; Kim, D.J.; Kim, J.H.; Kim, Y.T.; Lee, M.Y.; Yoon, S.J.; Lee, D.H. Effectiveness of the Charleston night-time bending brace in the treatment of adolescent idiopathic scoliosis. J. Pediatr. Orthop. 2012. [CrossRef]

34. Coillard, C.; Leroux, M.A.; Zabjek, K.F.; Rivard, C.H. SpineCor-A non-rigid brace for the treatment of idiopathic scoliosis: Post-treatment results. Eur. Spine J. 2003. [CrossRef]

35. Gutman, G.; Benoit, M.; Joncas, J.; Beauséjour, M.; Barchi, S.; Labelle, H.; Parent, S.; Mac-Thiong, J.M. The effectiveness of the SpineCor brace for the conservative treatment of adolescent idiopathic scoliosis. Comparison with the Boston brace. Spine J. 2016. [CrossRef]

36. Weiss, H.R.; Werkmann, M. Retraction: Soft braces in the treatment of Adolescent Idiopathic Scoliosis (AIS)—Review of the literature and description of a new approach. Scoliosis 2013, 8, 7. [CrossRef] [PubMed]

37. Van Loon, P.J.M.; Kühbauch, B.A.G.; Thunnissen, E. Forced lordosis on the thoracolumbar junction can correct coronal plane deformity in adolescents with double major curve pattern idiopathic scoliosis. Spine (Phila. Pa. 1976). 2008, 33, 797-801. [CrossRef]

38. Veldhuizen, A.G.; Cheung, J.; Bulthuis, G.J.; Nijenbanning, G. A new orthotic device in the non-operative treatment of idiopathic scoliosis. Med. Eng. Phys. 2002. [CrossRef]

39. Wong, M.S.; Cheng, J.C.Y.; Lam, T.P.; Ng, B.K.W.; Sin, S.W.; Lee-Shum, S.L.F.; Chow, D.H.K.; Tam, S.Y.P. The effect of rigid versus flexible spinal orthosis on the clinical efficacy and acceptance of the patients with adolescent idiopathic scoliosis. Spine (Phila. Pa. 1976). 2008. [CrossRef] [PubMed]

40. Weiss, H.R. SpineCor vs. natural history - Explanation of the results obtained using a simple biomechanical model. Stud. Health Technol. Inform. 2008. [CrossRef]

41. Bassett, G.S.; Bunnell, W.P.; MacEwen, G.D. Treatment of idiopathic scoliosis with the Wilmington brace. Results in patients with a twenty to thirty-nine-degree curve. J. Bone Joint Surg. Am. 1986, 68, 602-605. [CrossRef]

42. Périé, D.; Aubin, C.E.; Petit, Y.; Beauséjour, M.; Dansereau, J.; Labelle, H. Boston brace correction in idiopathic scoliosis: A biomechanical study. Spine (Phila. Pa. 1976). 2003. [CrossRef]

43. Rivett, L.A.; Stewart, A.; Potterton, J. The effect of compliance to a Rigo System Cheneau brace and a specific exercise programme on idiopathic scoliosis curvature: A comparative study: SOSORT 2014 award winner. Scoliosis 2014. [CrossRef] 
44. De Mauroy, J.C.; Lecante, C.; Barral, F.; Daureu, D.; Gualerzi, S.; Gagliano, R. The Lyon brace. Disabil. Rehabil. Assist. Technol. 2008. [CrossRef]

45. de Mauroy, J.C.; Journe, A.; Gagaliano, F.; Lecante, C.; Barral, F.; Pourret, S. The new Lyon ARTbrace versus the historical Lyon brace: A prospective case series of 148 consecutive scoliosis with short time results after 1 year compared with a historical retrospective case series of 100 consecutive scoliosis; SOSORT award 2015 winner. Scoliosis 2015. [CrossRef] [PubMed]

46. Aulisa, A.; Guzzanti, V.; Perisano, C.; Falciglia, F.; Maggi, G.; Aulisa, L. Treatment of lumbar curves in adolescent females affected by idiopathic scoliosis with a progressive action short brace (PASB): Assessment of results according to the SRS committee on bracing and nonoperative management standardization criteria. Scoliosis 2012. [CrossRef]

47. Gepstein, R.; Leitner, Y.; Zohar, E.; Angel, I.; Shabat, S.; Pekarsky, I.; Friesem, T.; Folman, Y.; Katz, A.; Fredman, B. Effectiveness of the Charleston bending brace in the treatment of single-curve idiopathic scoliosis. J. Pediatr. Orthop. 2002. [CrossRef]

48. Grivas, T.B.; Bountis, A.; Vrasami, I.; Bardakos, N.V. Brace technology thematic series: The dynamic derotation brace. Scoliosis 2010. [CrossRef] [PubMed]

49. Spoonamore, M.J.; Dolan, L.A.; Weinstein, S.L. Use of the Rosenberger brace in the treatment of progressive adolescent idiopathic scoliosis. Spine (Phila. Pa. 1976). 2004, 29, 1458-1464. [CrossRef]

50. Negrini, S.; Marchini, G.; Tessadri, F. Brace technology thematic series-The Sforzesco and Sibilla braces, and the SPoRT (Symmetric, Patient oriented, Rigid, Three-dimensional, active) concept. Scoliosis 2011. [CrossRef]

51. Colbert, A.P.; Craig, C. Scoliosis management in Duchenne muscular dystrophy: Prospective study of modified Jewett hyperextension brace. Arch. Phys. Med. Rehabil. 1987, 68, 302-304.

52. Wang, S.V.; Zing, S. Bracing Effects of the Flexpine in Scoliosis Patients. Am. Sci. Res. J. Eng. Technol. Sci. 2017, 34, 261-268.

53. Coillard, C.; Circo, A.; Rivard, C.H. A new concept for the non-invasive treatment of Adolescent Idiopathic Scoliosis: The Corrective Movement@ principle integrated in the SpineCor system. Disabil. Rehabil. Assist. Technol. 2008. [CrossRef]

54. Morningstar, M. Outcome observations in patients using a scoliosis activity suit: A retrospective chart review after one-year follow-up. J Scoliosis Rehabil 2013, 2013, 1-10.

55. Richards, B.S.; Bernstein, R.M.; D'Amato, C.R.; Thompson, G.H. Standardization of criteria for adolescent idiopathic scoliosis brace studies: SRS Committee on Bracing and Nonoperative Management. Spine (Phila. Pa. 1976). 2005. [CrossRef] [PubMed]

56. Negrini, S.; Donzelli, S.; Aulisa, A.G.; Czaprowski, D.; Schreiber, S.; de Mauroy, J.C.; Diers, H.; Grivas, T.B.; Knott, P.; Kotwicki, T. 2016 SOSORT guidelines: Orthopaedic and rehabilitation treatment of idiopathic scoliosis during growth. Scoliosis Spinal Disord. 2018, 13, 3. [CrossRef] [PubMed]

57. Exodynamics ExMS-1. Available online: https://www.exodynamicsmedical.com/ (accessed on 5 May 2020).

58. Igor, G.; Ryu, J.H.; Nedelchev, S. Twisted String Actuation Systems: Applications, Modelling, and Control; Elsevier Science: Amsterdam, The Netherlands, 2021; ISBN 9780128141953.

59. Gaponov, I.; Popov, D.; Lee, S.J.; Ryu, J.H. Auxilio: A portable cable-driven exosuit for upper extremity assistance. Int. J. Control. Autom. Syst. 2017. [CrossRef]

60. Seong, H.S.; Kim, D.H.; Gaponov, I.; Ryu, J.H. Development of a Twisted String Actuator-based Exoskeleton for Hip Joint Assistance in Lifting Tasks. In Proceedings of the IEEE International Conference on Robotics and Automation, Paris, France, 15 September 2020.

61. Medical, G. Green Sun Medical Brace. Available online: http:/ /www.greensunmedical.com/ (accessed on 8 December 2020).

62. Myontec No Title. Available online: https://www.myontec.com/ (accessed on 18 August 2020).

63. Redaelli, D.F.; Colombo, G.; Fraschini, P.; Biffi, E.; Reni, G. Current and future manufacturing of chest orthoses, considering the case of osteogenesis imperfecta. In Proceedings of the ASME Design Engineering Technical Conference, Quebec, QC, Canada, 26-29 August 2018.

64. Donzelli, S.; Zaina, F.; Negrini, S. In defense of adolescents: They really do use braces for the hours prescribed, if good help is provided. Results from a prospective everyday clinic cohort using thermobrace. Scoliosis 2012. [CrossRef] [PubMed]

65. Lou, E.; Hill, D.L.; Raso, J.V. A wireless sensor network system to determine biomechanics of spinal braces during daily living. Med. Biol. Eng. Comput. 2010. [CrossRef]

66. Lou, E.; Venkateswaran, S.; Hill, D.L.; Raso, J.V.; Donauer, A. An intelligent active brace system for the treatment of scoliosis. IEEE Trans. Instrum. Meas. 2004. [CrossRef]

67. Lou, E.; Benfield, D.; Raso, J.; Hill, D.; Durdle, N. Intelligent brace system for the treatment of scoliosis. Stud. Health Technol. Inform. 2002. [CrossRef]

68. Chalmers, E.; Lou, E.; Hill, D.; Zhao, V.H.; Wong, M.S. Development of a pressure control system for brace treatment of scoliosis. IEEE Trans. Neural Syst. Rehabil. Eng. 2012. [CrossRef]

69. Murray, R.C.; Ophaswongse, C.; Park, J.H.; Agrawal, S.K. Characterizing Torso Stiffness in Female Adolescents with and without Scoliosis. IEEE Robot. Autom. Lett. 2020. [CrossRef]

70. Santamaria, V.; Luna, T.; Khan, M.; Agrawal, S. The robotic Trunk-Support-Trainer (TruST) to measure and increase postural workspace during sitting in people with spinal cord injury. Spinal Cord Ser. Cases 2020. [CrossRef]

71. Khan, M.I.; Santamaria, V.; Kang, J.; Bradley, B.M.; Dutkowsky, J.P.; Gordon, A.M.; Agrawal, S.K. Enhancing Seated Stability Using Trunk Support Trainer (TruST). IEEE Robot. Autom. Lett. 2017. [CrossRef]

72. Santamaria, V.; Khan, M.; Luna, T.; Kang, J.; Dutkowsky, J.; Gordon, A.; Agrawal, S. Promoting Functional and Independent Sitting in Children with Cerebral Palsy Using the Robotic Trunk Support Trainer. IEEE Trans. Neural Syst. Rehabil. Eng. 2020. [CrossRef] 
73. Ophaswongse, C.; Murray, R.C.; Santamaria, V.; Wang, Q.; Agrawal, S.K. Human Evaluation of Wheelchair Robot for Active Postural Support (WRAPS). Robotica 2019. [CrossRef]

74. Ophaswongse, C.; Agrawal, S.K. Optimal design of a novel 3-DOF orientational parallel mechanism for pelvic assistance on a wheelchair: An approach based on kinematic geometry and screw theory. IEEE Robot. Autom. Lett. 2020. [CrossRef]

75. Bratic, D.; Noel, A. Vertebral decompression device. U.S. Patent 15/567,651, 29 March 2018.

76. Grazioso, S.; Selvaggio, M.; Di Gironimo, G. Design and development of a novel body scanning system for healthcare applications. Int. J. Interact. Des. Manuf. 2018. [CrossRef]

77. Grazioso, S.; Selvaggio, M.; Caporaso, T.; Di Gironimo, G. A Digital Photogrammetric Method to Enhance the Fabrication of Custom-Made Spinal Orthoses. J. Prosthetics Orthot. 2019. [CrossRef]

78. Guy, A.; Labelle, H.; Barchi, S.; Audet-Duchesne, E.; Cobetto, N.; Parent, S.; Raison, M.; Aubin, C.-É. Braces Designed Using CAD/CAM Combined or Not with Finite Element Modeling Lead to Effective Treatment and Quality of Life after Two Years. Spine (Phila. Pa. 1976). 2020. [CrossRef] [PubMed]

79. Weiss, H.R.; Seibel, S.; Moramarco, M.; Kleban, A. Bracing scoliosis: The evolution to CAD/CAM for improved in-brace corrections. Hard Tissue 2013, 2, 43. [CrossRef]

80. Mauroy, J.C.D.; Lecante, C.; Barral, F.; Pourret, S. Prospective study and new concepts based on scoliosis detorsion of the first 225 early in-brace radiological results with the new Lyon brace: ARTbrace. Scoliosis 2014. [CrossRef]

81. Cobetto, N.; Aubin, C.E.; Parent, S.; Clin, J.; Barchi, S.; Turgeon, I.; Labelle, H. Effectiveness of braces designed using computeraided design and manufacturing (CAD/CAM) and finite element simulation compared to CAD/CAM only for the conservative treatment of adolescent idiopathic scoliosis: A prospective randomized controlled trial. Eur. Spine J. 2016. [CrossRef]

82. Cobetto, N.; Aubin, C.É.; Parent, S.; Barchi, S.; Turgeon, I.; Labelle, H. 3D correction of AIS in braces designed using CAD/CAM and FEM: A randomized controlled trial. Scoliosis Spinal Disord. 2017. [CrossRef] [PubMed]

83. Li, J.; Tanaka, H. Feasibility study applying a parametric model as the design generator for 3D-printed orthosis for fracture immobilization. 3D Print. Med. 2018. [CrossRef] [PubMed]

84. Li, J.; Tanaka, H. Rapid customization system for 3D-printed splint using programmable modeling technique-A practical approach. 3D Print. Med. 2018. [CrossRef] [PubMed]

85. Patterson, A.E.; Pereira, T.R.; Allison, J.T.; Messimer, S.L. IZOD impact properties of full-density fused deposition modeling polymer materials with respect to raster angle and print orientation. Proc. Inst. Mech. Eng. Part C J. Mech. Eng. Sci. 2019. [CrossRef]

86. Lanzotti, A.; Martorelli, M.; Maietta, S.; Gerbino, S.; Penta, F.; Gloria, A. A comparison between mechanical properties of specimens 3D printed with virgin and recycled PLA. In Proceedings of the Procedia CIRP, Napels, Italy, 18-20 July 2019.

87. Chan, W.Y.; Yip, J.; Yick, K.L.; Ng, S.P.; Lu, L.; Cheung, K.M.C.; Kwan, K.Y.H.; Cheung, J.P.Y.; Yeung, K.W.K.; Tse, C.Y. Mechanical and Clinical Evaluation of a Shape Memory Alloy and Conventional Struts in a Flexible Scoliotic Brace. Ann. Biomed. Eng. 2018. [CrossRef] [PubMed]

88. Narang, Y.S.; Vlassak, J.J.; Howe, R.D. Mechanically Versatile Soft Machines through Laminar Jamming. Adv. Funct. Mater. 2018. [CrossRef]

89. Wang, T.; Zhang, J.; Li, Y.; Hong, J.; Wang, M.Y. Electrostatic Layer Jamming Variable Stiffness for Soft Robotics. IEEE/ASME Trans. 2019. [CrossRef]

90. Choi, W.H.; Kim, S.; Lee, D.; Shin, D. Soft, Multi-DoF, Variable Stiffness Mechanism Using Layer Jamming for Wearable Robots. IEEE Robot. Autom. Lett. 2019. [CrossRef] 